\title{
Study on the Practical Teaching Reform of Business Administration Major in Colleges and Universities under the Economic Transformation of Resource- based Cities*
}

\author{
Congxi He \\ Petroleum and Economic Management Institute \\ Northeast Petroleum University \\ Daqing, China
}

$$
\text { Ying Chu }
$$

Petroleum and Economic Management Institute Northeast Petroleum University

Daqing, China

\author{
Hailing Miao \\ Petroleum and Economic Management Institute \\ Northeast Petroleum University \\ Heilongjiang Bayi Agricultural University \\ Daqing, China 163318
}

\section{Xuan Li}

Petroleum and Economic Management Institute Northeast Petroleum University

Daqing, China

\begin{abstract}
Practical teaching is an important content for talent training in undergraduate teaching, and it is far from enough to rely solely on pure theory teaching to adapt to the requirements of educational development under the background of new situation and new ideas in the new age. This is because students are not only required to have rich knowledge in economics and business management, but also to have corresponding abilities of practical operation, flexible communication, adaption to social environment, independent analysis and judgment as well as teamwork so as to meet the requirements of business administration posts in the new era. Therefore, it is imperative to discuss the practical teaching reform of business administration major in colleges and universities under economic transformation of resource-based city. By analyzing current development situation of practical teaching of business administration major, the paper discusses major problems existing in practical teaching of business administration major, and put forwards corresponding countermeasures.
\end{abstract}

Keywords-resources-based city; economic transformation; business administration in colleges and universities; reform of practical teaching

\section{INTRODUCTION}

Since the 21 st century, with the constant deepening of economic transformation, most resource-based cities find themselves in a predicament of resource exhaustion and urban crisis. It is an urgent problem to be discussed and studied about how to help these cities out the predicament

*The thesis is the phased achievements of the scientific research project "Research on Precision Marketing Path and Mechanism of Enterprise in Big Data Era" of Heilongjiang Provincial Planning Office of Philosophy and Social Science. Project number: 16GLD01. and realize sustainable development. For resource-based cities, to realize sustainable development, the important premise is optimization of talent management. However, Daqing, the boom town based on oil resources are faced with many problems in human resource management such as lack of scientificity, structure disequilibrium, disproportionality, bad quality and insufficient guarantee. Under the background of economic transformation of Daqing-the oil city, it is an important topic for colleges and universities about how to adapt business administration teaching to the requirements of talent training after economic transformation and enhance innovation in practical teaching to train students in an effective way.

\section{CuRrent DEVElopMENT SituAtion OF PRACTICAL TEACHING OF BUSINESS ADMINISTRATION MAJOR}

For many years, adhering to the idea of schooling "rely on the natural resources, insist on combination of school and enterprise, try practical teaching and train practical talents", colleges and universities in resource-based cities have been insisting on developing applied top talents, highlighting teaching and scientific research, exploring innovative reform of teaching and strengthening the development of students' innovative and practical ability, so the quality of students trained has been gradually improved. As a result, they have made some progress in training of business administration majors. Especially, they also made a bold trial in practical teaching specific to economic transformation of resourcebased cities, and business administration major of Northeast Petroleum University is a representative example of this. 


\section{A. Laboratory Construction}

Practical teaching is increasingly important in education and resource construction is the key factor of laboratory construction. In recent years, the School of Economics and Management has invested millions for construction of professional laboratory. Laboratory of business administration major, with teaching experiment room of 700 square meters currently, has established 3 modern standard laboratory rooms, with a total value of RMB 2 million of the apparatus and equipment, RMB 35 million of laboratory equipment for raw materials. Sue to the site construction, the professional laboratory has not opened to the students.

With over 200 apparatus and equipment currently, mainly based on newly introduced equipment, including high-performance PC, network sever, projector equipment, laser printer, the professional laboratory has also introduced new simulated sand table, ERP system and other experimental software. Through carefully investment, the professional laboratory has reached a high level and provide with ideal teaching guarantee for experimental curriculum. This professional laboratory can now open 7 professional experimental courses such as relational data base, management information system, principle of statistics and industrial statistics, e-commerce, analysis of business economic activities, operational research and etc., covering most major professional courses, with 35 experimental items, and $100 \%$ of the experiment rate. The experimental items, covering various types of experiments in the undergraduate stage of business administration major, play a role in cultivating students' ability to finding, analyzing, and solving problems. Experiment teaching plays a key role in cultivating students' ability to practice, innovation and improvement, which lays a solid foundation for the training of professional talents in the new era.

\section{B. Practice Base Construction}

Practice base is one of the main battlefields of practice teaching. In terms of base construction, business administration major attaches great importance to schoolenterprise cooperation. Through the establishment of practice bases, students can directly contact, recognize and understand the enterprise business administration practices, strengthen the ability to innovate and solve problems, and also enable enterprises to improve their business administration level and business innovation consciousness through practical guidance. Through scientific research cooperation, scientific and technological development, consulting services and other ways, the school has established long-term cooperative relations with enterprises and institutions, signing with 10 large and medium enterprises, constructing practical base of fixed point and fixed place, including Daqing Petrochemical Company, Daqing Refining \& Chemical Company, Ove Profile Co., Ltd., Sanwei Company, Mindawell Co., Ltd., Daqing Oilfield No. 2 Production Plant, No. 8 Production Plant, Xiao Xue Beer Company, Jean Hu Road Mall and so on for students' internship.
Through construction of base and students' standardized internships, the students recognize the characteristics, production and business models and the direction of production and business of various enterprises, combining the learned knowledge and real enterprises, greatly enhancing their ability to adapt society. For example, many of the suggestions made by students during internship in Mingdawell Company have been adopted by the company and have achieved some results, which are well praised by enterprises. In order to strengthen the construction of the base, business administration major also annually invest certain money for base maintenance construction, which improves the practical teaching environment and the internship effect has been obviously improved.

\section{MaIn Problems Existing IN THE Practice TEACHING OF BUSINESS ADMINISTRATION}

Practice teaching is an important type of business administration major, which profoundly influences the innovation development of college students. However, the current development of professional practice teaching is not ideal, which is mainly manifested in several aspects:

\section{A. Insufficient Ideological Understanding}

At present, leaders and teachers of some colleges and universities are influenced by the inertia effect of traditional education, and they have insufficient understanding of significance and effect of practice teaching, which leads to the practice teaching link to go through the field, engage in forms, especially the graduation practice is unguided and unsupervised. In the teaching process, school teaches the knowledge in the classroom as the main task of teaching, instead, it regards the practice teaching as a supplementary form of classroom teaching ${ }^{[1]}$. Therefore, once theoretical teaching and practical teaching encounter conflicts in various aspects, it is common to give up practice teaching. Due to the weaker position of practice teaching, the practice teaching content, method and management measures are less invested, which puts practice teaching in a vague position and directly leads to quite a number of students lack of awareness of the significance of practice teaching, lack of attention, resulting the insufficient practice teaching, and difficult to achieve the innovation teaching of business administration major.

\section{B. Insufficient Cooperation Between Universities and Enterprises, Lack of Innovation of Practice Teaching}

At present, due to the lack of resources, there is less and less connection between universities and enterprises, difficulties in base construction, no certain link between the two sides, the great gap between the theoretical learning in campus and the production and business practice of enterprises. All of the above signs show that there are still many problems of practice teaching in universities under the economic transformation of resources cities. Nowadays, due to the exhaustion of resources, such as the annual production of oil of Daqing oilfield has reduced to 40 million tons, thus how do the enterprises accept the students' internship when they are reluctant to protect themselves? In addition, there is little about business administration practice in resource 
enterprises, with certain difficulty to accept professional students' internship, thus affecting the practice teaching effect of professional students.

At present, the practice teaching in colleges and universities is mainly limited to the knowledge of practice, the form of production practice, lack of targeted graduation practice, flexible and diversified teaching links which is beneficial for students to integrate with social work as soon as possible. The practice teaching lacks originality, and it is very different from the new education normal.

\section{Incomplete Practice Teaching Skills of Teachers}

Business administration major, a high practical discipline, requires strictly for teachers' comprehensive teaching ability. But there has been a shortage of "double types" teachers nowadays, on the one hand, teachers are busy completing the teaching tasks, and neglecting the teaching research and reform of business administration major closely related to market economic practice; on the other hand, the pressure caused by the research and award of the requirement for promotion teachers, insufficient in teaching themselves, teaching research and teaching reform, and lack of deep problems in the field of professional teaching. In the teaching process, pay attention to knowledge imparting and lack of ability to cultivate; pay attention to teaching implementation and neglect application of theory; pursue teaching skills and methods and lack "teaching interaction"; pay attention to teaching input and despise students' cognition, etc. The link of systematic work of business administration actually done by teachers is deficient; less teachers have experience of working in the oilfield; there is no further research, analysis and discussion of business administration practice of teachers, and serious lack of professional practice teaching skills.

\section{COUNTERMEASURES OF REFORM OF PROFESSIONAL} PRACTICE TEACHING IN BUSINESS ADMINISTRATION MAJOR

\section{A. Change the Concept and Raise Awareness of Practical Teaching}

Thoroughly change the concept of paying more attention to classroom teaching, and less to practice education, and raise the concept of practice teaching in cultivating theoretic knowledge, business ability and comprehensive ability of students, putting practice teaching in the key position of teaching in colleges and universities. Therefore, colleges and universities shall make clear that practice teaching occupies a very important position in the whole teaching, and it shall be emulated in teaching and training system for students in business administration major of various practical activities in and out of $\mathrm{school}^{[2]}$. First of all, in order to cultivate students' abilities of professional skills of business administration, problem analysis and judgment, prediction and business management internal and external cooperation etc., it is far from enough by relying on classroom teaching, and it is a must to increase the strength of the practice links inside and outside school. Secondly, practice links are the important process to improve the quality of professional teaching, which is the main embodiment of the combination of theory and practice, and the key point to apply the relative theory to professional practice activities so that to improve the overall quality and effect of teaching. Thirdly, it is one of the most effective ways to cultivate practical talents to improve the comprehensive ability of professional teachers and students through practice teaching links. Thus all professional teachers must realize the significance of practical teaching, renew the teaching concept, accurate position of practical teaching, pay more attention to the cultivation of students' work skills, adaptability of industrial and commercial works, and eliminate the misunderstanding of various aspects of practical teaching.

\section{B. Encourage Students to Create "Simulation Companies" While Strengthening University-run Enterprises Cooperation}

Colleges and universities shall carry out multi-level communication with enterprises, and understand and grasp the demand information of business administration of the society, especially the leaders of colleges and universities shall communicate more with enterprises to establish and improve a smooth cooperation guarantee system between universities and enterprise. As for the established off-campus practice bases, it shall be listed on the mature condition so that to normalize the operation of internship bases and manage them scientifically and effectively. Make effort to the substantive issues of cooperation between colleges and universities and enterprises to realize the effective allocation of practical teaching resources. Establish operation system of the internship bases to effectively manage the internship bases and provide more opportunities for industrial and commercial practice. Through off-campus internship, there will be more opportunities for students to practice and enhance the perceptual knowledge of their major in practice so that to improve the abilities of practice and comprehensive application of professional skills of students.

Because of the great importance of off-campus internship, the reform and innovation of practical teaching in campus must be paid highly attention to. Therefore, it is a good idea to encourage students to establish virtual enterprises ${ }^{[3]}$. With the introduction of virtual enterprises, students can impact on each department in the enterprises, can directly carry out business transactions with other simulated enterprises, and can directly contact with simulated social economic department. Through simulated business activities, students can experience business management personally on the scene; through simulated practice, students can understand and know all theories, knowledge and regulations and policies of the job; through simulated training, it can strengthen students' sense of responsibility, team innovation spirit and mutual assistant and integrate with the society as soon as possible.

\section{Reform and Improve the Structure of Professional Teachers, Increase the Quantity of "Double Teachers"}

First of all, colleges and universities shall enhance the "teacher" position of experimental source of teachers, and let "double teachers" with abundant practice teaching experience stand in the practice teaching "first-line" 
classroom. First with the requirement of practice teaching, colleges and universities shall establish fair compensation system for class hour of practice teaching theory to ensure the available treatment for teachers of practice teaching. Then, colleges and universities shall grasp all opportunities to train the experimental teachers, such as let them attend professional skills training, obtain relative job qualification certificate, etc. Meanwhile, it is necessary to encourage the theoretical teachers to involve deeply in the enterprises, and exchange the resources through the platform of universities and enterprises. After the economic transformation of resource-based city, the knowledge structure of graduate students in business administration major is very high, thus it can be known how strict with the teachers' knowledge and ability under the urban economic transformation in the new era, and professional teachers must attend the actual project and work of business administration with plans and purpose. Thirdly, from the perspective of "quality and efficiency", universities shall greatly improve the structure of teachers' team, make an effort to stabilize and introduce business administration teachers with rich experience in practical teaching, and ensure there is a practice teaching team with high comprehensive quality, available knowledge structure, stable work, and strong comprehensive ability standing in the first-line of practice teaching.

\section{CONCLUSION}

In addition, it is necessary to vigorously develop and strengthen the construction of "tertiary industry" in colleges and universities, on the one hand, university-run enterprises can generate income for school to solve the problem of insufficient funds, on the other hand, it can be improved of practice teaching level of teachers' by attending to the work of university-run enterprises, and it can be enhanced of students' practical ability by participating in the internship in university-run enterprises so that to promote the rapid development of practice reform of business administration major in colleges and universities.

\section{REFERENCES}

[1] Li Xuxuan. Problems and countermeasures of practice teaching of business administration in applied undergraduate colleges and universities. Education Exploration, 2013-02-25 李旭轩. 应用型本科 院校工商管理专业实践教学存在的问题及对策. 《教育探索》. 2013-02-25

[2] Yin Zhihong, Xue Hongyan, Wang Yanqiu, Cui Mingxin. Construction of experiential teaching system based on practical thinking. National business (theoretical research), 2013-09-18-201309-18 尹志红;薛红燕;王艳秋;崔明欣.基于实践性思维的工商管理 专业体验式教学体系构建《全国商情(理论研究)》.2013-09-182013-09-18

[3] Zhnag Jinhuan, Song Xiaohua. Construction and practice of practice teaching system of marketing major. Journal of Shijiazhuang University, 2017-07-20 张金环; 宋晓华.市场营销专业实践教学体 系建设与实践. 《石家庄学院学报》.2017-07-20 